\title{
БІБЛІОГРАФІЯ ПРАЦЬ Наталії Хобзей
}

\section{0}

Міфоантропоніми жіночого роду у демонології Гуцульщини // Екологія культури: історія, традиції, сучасність / відп. ред. М. Бевз, Я. Грицак. Львів, 1990. С. 71.

1993

До питання українського шкільництва у Великобританії // II Міжнародний конгрес україністів: Мовознавство. Львів, 1993. С. 150-152.

1994

Другий конгрес Міжнародної асоціації україністів // Хлібороб (Бразилія).1994. № 239. Квітень. С. 3.

Міфологічна лексика Гуцульщини // Гуцульщина: перспективи іiі соціальноекономічного розвитку в незалежній Україні. Івано-Франківськ, 1994. С. 118-119.

Чоловік, що може перемітуватися на вовка // Просвіта. Львів, 1994. Вип. 14 (139). C. 4-5.

\section{5}

Міфологічна лексика українських творів карпатського ареалу: автореферат дис. ... канд. філол. наук. Львів, 1995. 24 с.

\section{6}

Матеріали для дослідження української демонології (фольклористичний і мовознавчий аспекти їх збирання) // Українська історична та діалектна лексика. Вип. 3. Львів: Інститут українознавства ім. І. Крип'якевича НАН України, 1996. C. 181-186.

\section{7}

[укл.:] Гуцульські говірки: Короткий словник / відп. ред. Я.В. Закревська. Львів: Інститут українознавства ім. І.Крип’якевича НАН України, 1997. 232 с. [співукл.: Г. Гузар , Я. Закревська, В. Зеленчук]. 
1998

Карпато-українсько-південнослов'янські лексичні паралелі (міфологічні назви) // Матеріали міжнародної славістичної конференції пам'яті проф. К. Трофимовича, 1-3 квітня 1998 р. Т. 1. Львів, 1998. С. 90-93.

Лексика духовної культури говірки с. Бродина (за працями О. Горбача) // Українська мова на Буковині: минуле і сучасне. Чернівці, 1988. С. 59-65.

Словник як джерело дослідження міфологічної лексики // Українська філологія: шкали, постаті, проблеми. Ч. ІІ. Львів, 1999. С. 50-59.

\section{9}

[рец.:] Як много важить слово // Гуцульщина: Ілюстрований журнал всегуцульської єдности. Ч. 56. Торонто. Липень, 1999. С. 10-11.

2000

Обдумував іï у людській мові: Ст. Вінценз “На високій полонині” // Гуцульські говірки: Лінгвістичні та етнолінгвістичні дослідження. Львів: Інститут українознавства ім. І. Крип'якевича НАН України, 2000. С. 48-54.

Між світом та антисвітом: чоловік, шо може перемітуватися на вовка // Гуцульські говірки: Лінгвістичні та етнолінгвістичні дослідження. Львів: Інститут українознавства ім. І. Крип'якевича НАН України, 2000. С. 48-54.

Український діалектологічний збірник: Огляд // Український гуманітарний огляд. Вип.3. Критика, 2000. С. 275-278.

Лексика духовной культуры украинских гворов карпатского ареала // $3^{\text {rd }}$ International Congres of Dialectologist and Geolinguists. Abstract book. Suplement. Lublin, 2000. C. 4.

Міфологічна лексика у матеріалах М. Грицака // Сучасні проблеми мовознавства та літературознавства. Вип. 3. Ужгород, 2000. С. 218-222.

[рец. на:] Гриценко П.Ю., Воронич Г.В., Дорошенко Л.І. та ін. Говірки Чорнобильської зони. Системний опис / за ред. П.Ю. Гриценка. Київ: Довіра, 1999. 271 с. // Записки Наукового товариства ім. Шевченка. Т. 239: Праці Філологічної секції. Львів, 2000. С. 625-630.

[рец. на:] Мартинова Г.І. Лінгвістична географія Правобережної Черкащини. Черкаси: Відлуння, 2000. 265 с. // Записки Наукового товариства ім. Шевченка. Т. 239: Праці Філологічної секції. Львів, 2000. С. 635-638.

Ярослава Закревська // Гуцульщина: Ілюстрований журнал всегуцульської єдности. Ч. 60. Торонто. Липень, 2000.

Шістдесятиріччя відділу української мови // Наше слово. 2000. № 51 (2264). 17 грудня. С. 8. [співавт.: Г. Дидик-Меуш].

У струну гуцульської душі // Книжковий світ. Львів, 2000. № 3-4 (16). С. 12. [співавт.: Г. Дидик-Меуш].

2001

Лексеми із коренем відь в українських говірках Карпат // Сучасні проблеми мовознавства та літературознавства: Українське і слов'янське мовознавство. Вип. 4. Ужгород, 2001. С. 534-537. 
До питання про лексичні та семантичні карпато-південнослов'янські паралелі // Волинь - Житомирщина: Історико-філологічний збірник з регіональних проблем. № 6 / ред. В. Сршов, В. Мойсієнко. Житомир, 2001. С. 170-176.

О наименовании тих, що щось знають в гуцульских говорах // Живая старина. Москва, 2001. № 3 (31). С. 21-22.

До 100-річчя Язикової комісії НТШ // Вісник Наукового товариства імені Шевченка. Львів, 2001. № 26. С. 14-17 [співавт.: У. Сдлінська].

Гуцульські говірки як об'єкт діалектної лексикографії // Ukrainistika na prahu nového století a tisíciletí: Problémy jazyka, literatury a kultury. 1. Olomoucké sympozium ukrajinistů. Sborník př́íspěvků. Olomouc, 2001. S. 100-106.

Про назви зі значенням 'найстарший чорт' у гуцульських говірках // Вісник Луганського державного педагогічного університету імені Тараса Шевченка. Філологічні науки. № 12 (44). Луганськ, 2001. С. 79-89.

2002

Гуцульська міфологія: етнолінгвістичний словник. Львів, 2002. 216 с.

Лексика говірки села Красний на Мараморощині в Румунії // Język mniejszości w otoczeniu obcym / red. J. Riger. Warszawa, 2002. S. 209-215.

Назви домашнього чорта, який приносить багатство, у говірках південнозахідного наріччя // Лінгвістичні студії. Вип. 9 / за ред. А. Загнітка. Донецьк, 2002. C. 224-228.

Лексика календарної обрядовості в українських говірках Мараморощини та Сучавщини на тлі гуцульських говірок // Rozprawy Slawistyczne. T. 19 / red. F. Szyżewski. Lublin: UMCS, 2002. C. 143-155.

Мова як джерело пізнання духовного світу народу (міфологічна лексика в українських говірках карпатського ареалу) // IV Міжнародний конгрес україністів: Мовознавство. Київ, 2002. С. 119-124.

2003

Временные ремарки в диалектных словарях // II Международная научная конференция “Язык и культура”: Тезисы докладов. Москва, 2003. С. 450-451.

[відп. ред.:] Діалектологічні студії. 1: Мова в часі і просторі: Збірник на пошану Дмитра Гринчишина. Львів: Інститут українознавства ім. І.Крип'якевича НАН України, 2003. 362 с. [співред.: П. Гриценко].

Міфологічні назви у Словнику української мови XVI - першої половини XVII століття // Ibid. C. 147-152.

[упор.:] Матеріали до бібліографії з проблем української діалектології за 2000-2001 роки // Ibid. C. 316-375.

Іван Панькевич - науковець, вчитель, громадський діяч [рец. на: Ivan Paňkevyс̌ a otázky spisovného jazyka: Štúdie a materially / zost. M. Mušinka. Prešov, 2002. 207 s.] // Ibid. C. 402-405.

[відп. ред.:] Діалектологічні студії. 2: Мова і культура / відп. ред. П. Гриценко, Н. Хобзей. Львів: Інститут українознавства ім. І.Крип'якевича НАН України, 2003. 362 с. [співред.: П. Гриценко].

Мовний простір міфологічних назв // Ibid. C. 53-63. 
Гончарство в мові і культурі // Ibid. C. 79-96 [співавт.: С. Литвиненко].

Była koza, witk i kapusta: рослини у польському фольклорі [рец. на: Stanisława Niebzhegowska, Przestrach od przestrachu: rośliny w ludowych przekazach ustnych. Lublin, 2000. 265 s.] // Ibid. C. 346-347 [співавт.: О. Сімович].

Порубіжжя: проблеми мови і культури [рец. на: Język i kultura na pogranichu polsko-ukraińsko-białoruskim / red. F. Czyżewski. Lublin, 2001. 377 s.] // Ibid. C. 334-338.

Етнолінгвістичні проблеми у східнослов'янській традиції [рец. на: Восточнославянский этнолингвистический сборник: Исследования и материалы / отв. ред. А.А. Плотникова. Москва, 2001. 496 с.] // Ibid. С. 339-343.

[відп. ред.:] Діалектологічні студії. 3: Збірник пам’яті Ярослави Закревської / відп. ред. П. Гриценко, Н. Хобзей. Львів: Інститут українознавства ім. І.Крип'якевича НАН України, 2003. 608 с. [співред.: П. Гриценко].

Ярослава Закревська: штрихи до портрету // Ibid. C. 9-13.

[упор.:] Листування Ярослави Закревської // Ibid. С. 40-84.

[упор.:] О. Горбач Словник говірки села Негостина (Румунія) // Ibid. С. 422-453.

[упор.:] О. Горбач Словник північно-підляської говірки села Добровода близько Гайнівки (Польща) // Ibid. C. 454-488. [співупор.: О. Тріль].

[рец.:] Дослідження українського мовного простору Румунії у студіях Івана Робчука мові // Ibid. C. 563-567.

[рец.:] Лексика українських говорів Східної Словаччини на картах Атласу Зузанни Ганудель // Ibid. C. 582-583.

Міфологічні назви у Словнику української мови XVI - першої половини XVII століття. 2 // Українська історична та діалектна лексика. Вип. 4. Львів: Інститут українознавства ім. І. Крип'якевича НАН України, 2003. С. 137-140

До питання синонімних відношень у гуцульських говірках // Język ukraiński: współczesność - historia / red. F. Czyżewski, P. Hrycenko. Lublin, 2003. S. 157-169.

2004

[відп. ред.:] Діалектологічні студії. 4: Школи, постаті, проблеми / відп. ред. П. Гриценко, Н. Хобзей. Львів: Інститут українознавства ім. І. Крип’якевича НАН України, 2004. 568 с. [співред.: П. Гриценко].

3 історії львівської діалектології // Ibid. C. 63-72.

[упор.:] Матеріали до бібліографії з проблем української діалектології за 20022003 роки // Ibid. C. 411-459.

[рец.:] “Зберігати сучасні явища для будучності”: записи закарпатських говірок на фонограф // Ibid. C. 544-548.

2005

[відп. ред.] Слово і доля: Збірник на пошану Уляни Сдлінської. Львів: Інститут українознавства ім. І. Крип'якевича НАН України, 2005. 368 с.

Із когорти співців гуцульського краю: Михайло Ломацький // Ibid. C. 351-355.

Міфологічна лексика в "Галицько-руських народних приповідках" Івана Франка // Записки Наукового товариства імені Шевченка. T. CCL: Праці філологічної секції. Львів, 2005. С. 449-468. 
[відп. ред.:] Діалектологічні студії. 5: Фонетика, морфологія, словотвір / відп. ред. П. Гриценко, Н. Хобзей. Львів: Інститут українознавства ім. І. Крип’якевича НАН України, 2005. 408 с. [співред.: П. Гриценко].

[рец.:] Записи закарпатських говірок: від давнини до сучасності // Ibid. C. 373375.

[рец.:] Енциклопедія білоруської міфології // Ibid. C. 376-377.

[рец.:] Ювілейне видання польських діалектологів // Ibid. C. 378-380.

Діалектологічні новинки // Ibid. C. 383-385.

2006

[відп. ред.:] Діалектологічні студії. 6: Лінгвістичний атлас - від створення до інтерпретації/ відп. ред. П. Гриценко, Н. Хобзей. Львів: Інститут українознавства ім. І.Крип'якевича НАН України, 2006. 432 с. [співред.: П. Гриценко].

[рец.:] Новаторство в царині української історичної діалектології // Ibid. С. 371-378. [співавт.: Г. Дидик-Меуш].

Проблема "свій - чужий (інший)" у мовному просторі Львова // Матеріали Міжнародної етнолінгвістичної конференції “Ороzycja swój / obcy (inny) w jézykach i kulturach słowiańskich”. Люблін, 2006. С. 17-18.

2007

3 історії лексикографічного дослідження гуцульського говору // Gwary dziś. 4: Konteksty dialektologii / pod. red. J. Sierociuka. Poznań, 2007. S. 77-85.

Свій / чужий (інший) у мовному просторі Львова // Etnolingwistyka: Problemy języka i kultury. 20 / red. J. Bartmiński. Lublin: UMCS, 2007. s. 111-123.

Мовний простір // Історія Львова. Т. 3 / за ред. А. Козицького. Львів. С. 442445.

2008

[відп. ред.:] Негрич М. Скарби гуцульського говору: Березови. Львів: Інститут українознавства ім. І.Крип'якевича НАН України, 2008 (серія “Діалектологічна скриня").

Березівська говірка на карті Гуцульщини // Ibid. C. 6-17 [співавт.: Т. Ястремська].

[відп. ред.:] Грицак М. Скарби гуцульського говору: Росішка (вівчарство у текстах). Львів: Інститут українознавства ім. І. Крип'якевича НАН України, 2008 [співред.: Т. Ястремська] (серія “Діалектологічна скриня”).

Невтомна праця Миколи Андрійовича Грицака // Ibid. C. 12-15.

[відп. ред.:] Діалектологічні студії. 7: Традиції і модерн / відп. ред. П. Гриценко, Н. Хобзей. Львів: Інститут українознавства ім. І.Крип’якевича НАН України, 2006. 416 с. [співред.: П. Гриценко].

[рец.:] Словник однієї говірки // Ibid. С. 367-370.

[рец.:] Різноаспектні дослідження сучасного говіркового мовлення // Ibid. C. 393-395.

[рец.:] Мовознавчі проблеми у листуванні Івана Панькевича та Івана Зілинського // Ibid. C. 395-397. 
[відп. ред.:] Шило Г. Наддністрянський регіональний словник. Львів; НьюЙорк, 2008. 288 с. [співред. Л. Полюга] (серія “Діалектологічна скриня”).

Культурне явище крізь призму українського діалектного словника // Діалектна мова: сучасний стан і динаміка в часі: До 100-річчя професора Ф.Т. Жилка. Київ, 2008. C. 198-200.

Діалектний словник: автор та читач // Сучасні проблеми мовознавства та літературознавства. Вип. 12: Українська діалектна лексика як об’єкт словникарства та лінгвогеографії (до 100-річчя від дня народження М.А. Грицака). Ужгород, 2008. С. 203-205 [співавт.: Т. Ястремська].

2009

Лексикон львівський: поважно і на жарт. Львів: Інститут українознавства ім. І. Крип'якевича НАН України, 2009. 672 с. [співавт.: О. Сімович, Т. Ястремська, Г. Дидик-Меуш] (серія “Діалектологічна скриня”).

Слова і місто, або місто в словах // Хобзей Н., Сімович О., Ястремська Т., Дидик-Меуш Г. Лексикон львівський: поважно і на жарт. Львів: Інститут українознавства ім. І. Крип'якевича НАН України, 2009. С. 7-43 (серія “Діалектологічна скриня").

[відп. ред.:] Діалектологічні студії. 8: Говори південно-західного наріччя / відп. ред. П. Гриценко, Н. Хобзей. Львів: Інститут українознавства ім. І. Крип’якевича НАН України, 2009. 372 с. [співред.: П. Гриценко].

2010

[відп. ред.:] Діалектологічні студії. 9: Запозичення та інтерференція / відп. ред. П. Гриценко, Н. Хобзей. Львів: Інститут українознавства ім. І. Крип'якевича НАН України, 2010. 616 с. [співред.: П. Гриценко].

Дещо про запозичення в мовленні львів'ян у контексті говірок південнозахідного наріччя // Ibid. C. 351-358.

[рец.:] Новий здобуток польської фразеології (на тлі українського контексту) // Ibid. C. 592-594.

Книжкові новинки для мовознавців // Ibid. C. 596-601 [співавт.: Н. Багнюк].

Система дієслова в гуцульських говірках // Ювілейний збірник на честь 80-річчя від дня народження професора Петра Лизанця. Ужгород, 2010. С. 586600 [співавт.: Т. Ястремська].

Дієслова вилітати, вилетіти у складі ідіом та паремій (на матеріалі говірок південно-західного наріччя української мови) // Лінгвістика. № 3 (21). Ч. 1 / відп. ред. К. Глуховцева. Луганськ, 2010. С. 206-209.

Дієслова 3 префіксом ви- в говірках північного і південно-західного наріч української мови: до пошуку паралелей // Волинь - Житомирщина: Історико-філологічний збірник з регіональних проблем / ред. В. Мойсієнко, В. Сршов. Житомир, 2010. Вип. 22 (I). С. 283-288.

Дієслова руху із префіксом ви-, або звідки та куди виходять, виїжджають і таке інше в колядках та щедрівках // Народна творчість українців в просторі та часі. Луцьк, 2010. С. 381-390. 
2011

[відп. ред.:] Українська мова в Галичині: історичний вимір. Львів: Інститут українознавства ім. І. Крип'якевича НАН України, 2011. 332 с. [співред.: Я. Ісаєвич, М. Мозер] (серія “Історія мови”).

У просторах воєнного часу. Про Першу світову війну в записах для “Атласу української мови" // Ibid. C. 267-310.

Багатозначні дієслова в говорах південно-західного наріччя: виводити-вивести // Мовознавчий вісник. Вип. 12-13 / відп. ред. Г. Мартинова. Черкаси, 2011. С. 100-105.

Багатозначні дієслова в говорах південно-західного наріччя: вискакувати / вискочити // Лінгвістика. № 1 (22). Ч. II / гол. ред. К. Глуховцева. 2011. С. 85-90.

Дієслова руху “знизу - вгору” в говірках південно-західного наріччя // Лінгвістика. № 3 (24). Ч. 1 / гол. ред. К. Глуховиева. 2011. С. 120-125.

Глагол в украинских диалектных словарях // Славянская диалектная лексикография. Материалы конференции / отв. ред. С.А. Мызников, О.Н. Крылова, И.В. Бакланова. Санкт-Петербург, 2011. С. 98-99.

Південно-західне наріччя української мови у студіях другої половини XIX століття // Діалектна мова: сучасний стан і перспективи дослідження, присвячені пам’яті діалектолога Валентини Прокопенко / відп. ред. Н.В. Гуйванюк. Чернівці, 2011. С. 70-72.

Префікс ви- на українських лінгвогеографічних картах // Науковий збірник Ужгородського університету. Серія: Філологія. Соціальні комунікації. Вип. 24. Присвячується 90-річчю від дня народження Й.О. Дзендзелівського. Ужгород, 2011. С. $195-198$.

Історичний та ареальний аспекти в дослідженні дієслів із префіксом ви- // Badania historycznojęzykowe. Stan, metodologia, perspektywy / red. B. Dunaj, M. Rak. Kraków, 2011. S. 297-310.

2012

Лексикон львівський: поважно і на жарт / 2-е вид. Львів: Інститут українознавства ім. І. Крип'якевича НАН України, 2012. 852 с. [співавт.: О. Сімович, Т. Ястремська, Г. Дидик-Меуш] (серія “Діалектологічна скриня”).

Гуцульський “всесвіт” у форматі діалектного словника // Вісник Прикарпатського університету: Філологія. Вип. 32-33. Івано-Франківськ, 2012. С. 281-285.

Дієслова руху із префіксом ви- в говірках південно-західного наріччя української мови: виходити / вийти // Gwary dziś. 6: Aktualne problemy dialektologii słowiańskiej / pod. red. J. Sierociuka. Poznań, 2012. S. 97-104.

2013

Гуцульські світи. Лексикон. Львів: Інститут українознавства ім. І. Крип’якевича НАН України, 2012. 668 с. [співавт.: Т. Ястремська, О. Сімович, Г. Дидик-Меуш] (серія “Діалектологічна скриня”).

Слова з гуцульських світів // Хобзей Н., Ястремська Т., Сімович О., Дидик-Меуш Г. Гуцульські світи. Лексикон. Львів: Інститут українознавства ім. I. Крип'якевича НАН України, 2012. С. 7-14. 
Украинский указатель. Index ukrainian // Общекарпатский диалектологический атлас: Указатели / под ред. Я. Ригера. Краков: Институт польского языка ПАН, 2012. С. 122-155 [співавт.: Т. Ястремська].

Місто у слові // Lwów: Lustro. Obraz wzajemny mieszkanców Lwowa w narracjach XX-XXI wieku. Warszawa: Instytut Slawistyki PAN, 2012. C. 67-78.

Атлас лінгвістичний // Наукове товариство імені Шевченка: Енциклопедія. Київ; Львів; Тернопіль, 2012. Т. 1. С. 348-350.

Атлас української мови // Наукове товариство імені Шевченка: Енциклопедія. Київ; Львів; Тернопіль, 2012. Т. 1. С. 350-351.

Дієслова із префіксом ви- в "Поученіях на євангеліє по Няговскому списку 1758 г.” // Мовні обрії: Збірник пам’яті Левка Полюги / відп. ред. О. Сімович. Львів, 2013. С. 172-179 (серія “Історія мови”).

2014

Аспекти дослідження дієслівного префікса ви- у говірках південно-західного наріччя української мови // Діалекти в синхронії та діахронії: загальнослов'янський контекст / відп. ред. П. Гриценко. Київ, 2014. С. 490-494.

2015

Лексикон львівський: поважно і на жарт / 3-е вид. Львів: Інститут українознавства ім. І. Крип’якевича НАН України, 2015. 896 с. [співавт.: О. Сімович, Т. Ястремська, Г. Дидик-Меуш].

[відп. ред.:] Діалектологічні студії. 10: Запозичення та інтерференція / відп. ред. П. Гриценко, Н. Хобзей. Львів: Інститут українознавства ім. І. Крип’якевича НАН України, 2015 [співред.: П. Гриценко].

Мовний світ гуцулів у форматі словника: Іван Вагилевич // Ibid. C. 51-61.

[рец.:] Українська діалектна морфологія сьогодення // Ibid. C. 585-589.

Назви Русин, руський в словниках і поза ними // Писемні пам'ятки: текст i контекст / відп. ред. Г. Дидик-Меуш. Львів: Інститут українознавства ім. I. Крип’якевича НАН України, 2015. С. 92-101 (серія “Історія мови”).

2016

Говірки суміжжя в діалектній лексикографіі: до проблеми опису // Сучасні проблеми мовознавства і літературознавства. Вип. 21. Ужгород, 2016. С. 162-166.

«Словник бойківського говору” о. Юрія Кміта та проблеми лексикографічного опису // Studia Ruthenica Cracoviensia. 11: Słowo u słowian. Wpływ języków sąsiadujących na rozwój języka ukraińskiego. Studia leksykalne / red. A. Budziak, W. Hojsak. Kraków, 2016. C. 85-95.

Структура діалектного словника: ілюстрація // Матеріали міжнародної науково-практичної конференції “Сучасна українська нація: мова, історія, культура”. Львів, 2016. C. $63-65$.

2017

Слова $з$ Болехова. Львів, 2017. 636 с. [співавт.: Гнатишак Ю., Сімович О., Ястремська Т.] (серія “Діалектологічна скриня”). 
[відп. ред.:] Гнатишак Ю., Сімович О., Хобзей Н., Ястремська Т. Слова з Болехова / Львів, 2017. 636 с. (серія “Діалектологічна скриня”).

[відп. ред.: Н Надсяння: Традиційна культура і побут (етнолінгвістичні матеріали) / упор. М. Глушко, Л. Хомчак. Львів, 2017. 592 с. (серія “Діалектологічна скриня").

Життєві та наукові стежки Івана Панькевича (до 130-річчя від дня народження) // Лінгвістика. № 2 (37) / відп. ред. К. Глуховцева. Старобільськ, 2017. С. 24-33.

2018

Етноніми південно-західного наріччя в діалектній лексикографії // IX Міжнародний конгрес україністів: Мовознавство (До 100-річчя Національної академії наук України) / гол. ред. Г. Скрипник. Київ, 2018. С. 521-531.

[відп. ред.:] Слов’янський світ Олафа Брока. Львів, 2018. [співред.: Т. Льоннгрен]. 262 c.

Українське тло студій Олафа Брока // Ibid. C. 246-262.

[відп. ред.:] Діалектологічні студії. 11: Слово - слоник - корпус / відп. ред. П. Гриценко, Н. Хобзей. Львів: Інститут українознавства ім. І.Крип'якевича НАН України, 2018. 374 с. [співред.: П. Гриценко].

Упорядники Ірина Романина, Тетяна Ястремська. 